Anais da Academia Brasileira de Ciências (2012) 84(1): 165-173

(Annals of the Brazilian Academy of Sciences)

Printed version ISSN 0001-3765 / Online version ISSN 1678-2690

www.scielo.br/aabc

\title{
A new species of Sarax Simon, 1892 from the Philippines (Arachnida: Amblypygi: Charinidae)
}

\author{
ALESSANDRO P.L. GIUPPONI and GUSTAVO S. MIRANDA \\ Laboratório de Aracnologia, Departamento de Invertebrados, Museu Nacional, Universidade Federal do Rio de Janeiro, \\ Quinta da Boa Vista, s/n, São Cristóvão, 20940-040 Rio de Janeiro, RJ, Brasil
}

Manuscript received on November 22, 2011; accepted for publication on February 23, 2012

\begin{abstract}
A new species of the genus Sarax Simon, 1892 is described from Panay Island, Philippines. Sarax curioi $\mathrm{sp} . \mathrm{n}$. is the second species of the genus from the country and can be distinguished from the other Philippine species (Sarax brachydactylus Simon, 1892) by the sclerotized granules of the pedipalp surface, the spines of the pedipalp distitibia, the number of denticles of the chelicerae claw and the shape of the denticles of the chelicerae basal segment. Sarax newbritainensis Rahmadi and Kojima, 2010 is newly recorded from New Ireland Island, Papua New Guinea.
\end{abstract}

Key words: Biodiversity, Southeast Asia, Taxonomy, Whip spider.

\section{INTRODUCTION}

Amblypygi are flattened arachnids with raptorial pedipalps and extremely elongate antenniform first legs, being commonly known as whip spiders. This order has approximately 160 species among five families distributed globally (Rahmadi et al. 2011). In the Southeast Asia, the amblypygid fauna encompasses the families Charinidae (with the genera Catageus Thorell, 1889, Charinus Simon, 1892 and Sarax Simon, 1892), Charontidae (with the genera Charon Karsch, 1879 and Stygophrynus Kraepling, 1895), Phrynidae (with the genus Phrynus Lamarck, 1801), and Phrynichidae (with the genus Phrynichus Karsch, 1879) (Harvey 2002, 2003). In this region, Sarax is the most diverse genus being composed by 12 species distributed on the continental and insular

Correspondence to: Alessandro Ponce de Leão Giupponi E-mail: agiupponi@gmail.com
Southeast Asia (from Laos to Indonesia) (Harvey 2003, Rahmadi et al. 2010). In the Philippines, just Sarax brachydactylus Simon, 1892 is recorded from the Luzon Island, Palawan Island and Cebu (Fig. 14). Although very similar to Charinus, mainly regarding the pedipalpalp tibia spination, Sarax can be distinguished by the presence of a ventral sac cover (Weygoldt 2000, Rahmadi and Kojima 2010). After studying a specimen sent by Dr. Eberhard Curio and examining some additional specimens, including the type series of Sarax brachydactylus, we recognized a new species from Malumpati, Antique Province, Panay Island, Philippines, which is described and illustrated here. To better visualize and compare both Philippine species of Sarax, pictures of $S$. brachydactylus are also given (Figs. 8-13). Moreover, a new record of Sarax newbritainensis Rahmadi and Kojima, 2010 is made. 


\section{MATERIALS AND METHODS}

The specimen was deposited in the National Museum of the Philippines, Manila. The observations, measurements and drawings were made using a stereomicroscope camera lucida (Wild). For measurements and nomenclature, we followed the proposals of Quintero (1981) in general. The article called tarsus by Quintero is here divided into distitarsus and tarsal claw (pretarsus) as the two articles are not fused in Charinidae. The pictures were taken with a Sony Cybershot DSC-V1 attached to the stereomicroscope. The measurements of pedipalp articles were taken between the external condiles of each segment, in order to establish fixed points and proper length measurements (illustration in Baptista and Giupponi 2002). The measurement accuracy is indicated in the legend of each figure.

The following abbreviations are used:

CAS - California Academy of Science, San Francisco, USA.

E.S - Eugène Simon.

MNHN - Muséum National d'Histoire Naturelle, Paris, France.

NMP - National Museum of the Philippines, Manila.

Comparative material: Sarax brachydactylus Simon, 1892: 1 juvenile MNHN 14801 (Type) E.S., 7 adults MNHN 14802 (Types) E.S., 1 adult and 2 juveniles MNHN 14803 (Types) E.S. Sarax davidovi Fage, 1946: 3 male and 1 juvenile MNHN (Types), Indochine, Mission C. Dawydoff, Mars, Avril-1939, Phaniang, S. Annam. Sarax newbritainensis Rahmadi and Kojima, 2010: 1 male (CAS) Papua New Guinea: Namatanai, New Ireland, 6-XII-1969, J.B. Tobler (Det. Giupponi and Miranda, 2011). Sarax willeyi Gravely, 1915: 1 male (CAS) Papua New Guinea: Madang Province, Baiteta road, 2,5 km W of North Coast Road, 60m, 3-III1989, D. H. Kavanaugh, G. E. Ball, N. D. Penny, and P. A. Meyer (Det. Giupponi and Miranda, 2011).

\section{Taxonomy}

\section{Family Charinidae Quintero 1986}

\section{Genus Sarax Simon 1892}

\section{Sarax curioi sp. n.}

(Figs. 1-7)

Etymology: The species name is a patronym in honor of Eberhard Curio, who kindly sent the specimen.

Type material: Female holotype: PHILIPPINES: Malumpati, 20-IX-2006, Bellhoff, D. (NMP).

Diagnosis: Sarax curioi $\mathrm{sp}$. n. can be characterized by the following features: sclerotized granules on the surface of the pedipalp; presence of corners on the anterior margin of the carapace, in front of the lateral eyes; geminate dorsal spines on the distitibia of the pedipalp; absence of denticles in the chelicerae claw; and the shape of the denticles of the basal segment of the chelicerae.

Description of female (holotype): Carapace (Figs. 1-2): flattened, wider than long (ratio a little less than $3 / 4$ ); prominent eyes, median eye tubercle dark-brown, without apical setae, triangular in shape; median eyes facing antero-laterally; lateral eyes close to the lateral margin of the carapace, yellowish pale in color; from the median eye tubercle starts a thin median furrow that reaches around the posterior area of the pair of lateral humps situated behind the lateral eye spots. Anterior margin with 6 small setae. Corners of the anterior margin extending downwards abruptly in front of the lateral eyes. Many tiny punctuations more abundant in the frontal area. Punctuations arranged in lines and spots, irradiating from the fovea and interspersed with smooth areas. 3 pairs of deep furrows and a deep, triangular fovea. The first pair of furrows placed just behind the lateral boss and not reaching the middle line. 3 lateral pairs of depressions (the first one placed over the first pair of furrows). Frontal process well developed, much longer than larger, with blunt, thickened apex. 

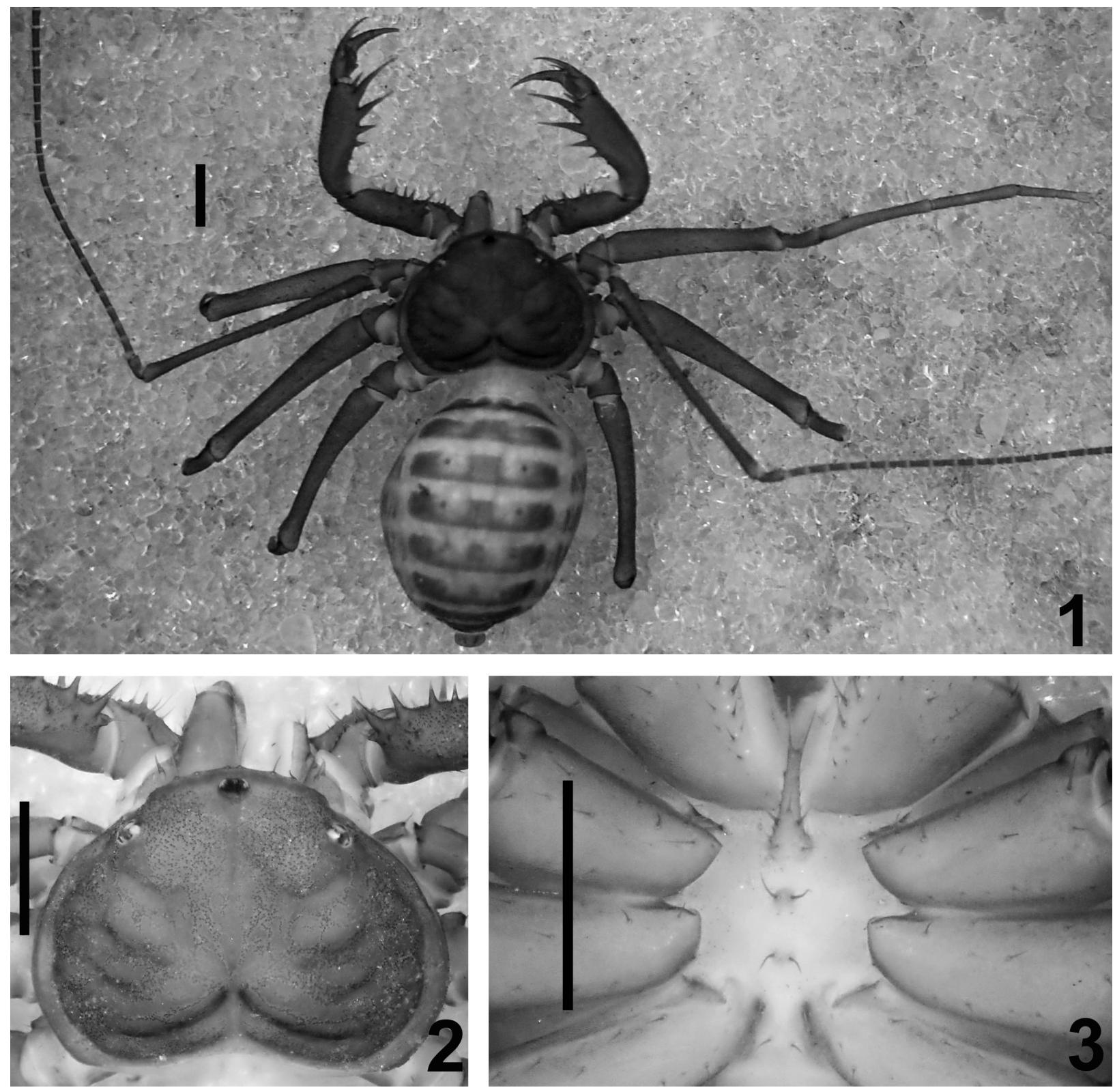

FIGURES 1-3: Sarax curioi sp. n. female holotype. 1 - Habitus. 2 - Carapace. 3 - Sternum. Scale bars: 1mm.

Sternum (Fig. 3): tri-segmented, all segments sclerotized and convex. Tritosternum with a round basis and projected anteriorly in a small blunt tubercle, with 2 apical, 3 medial and 2 basal setae, and some small setulae along the projection. Middle piece rounded, convex, with 2 setae and a few setulae. The third piece is also rounded and convex, but smaller and with smaller setae than the second piece. The second and third pieces are less sclerotized than the tristosternum. Sternites separated from each other by the diameter of the third piece.

Abdomen (Fig. 1): oblong, with almost indistinguishable punctuations, thinner than in the carapace. Chelicera: Cheliceral furrow (Fig. 7) with 4 internal teeth, the distal one bifid, the first cusp bigger than the second one. The fourth tooth twice as long as the others and much stouter. Teeth length (from tip to basis) $\mathrm{IV}>\mathrm{Ia}>\mathrm{Ib}=\mathrm{II}>\mathrm{III}$. Claw without denticles. 

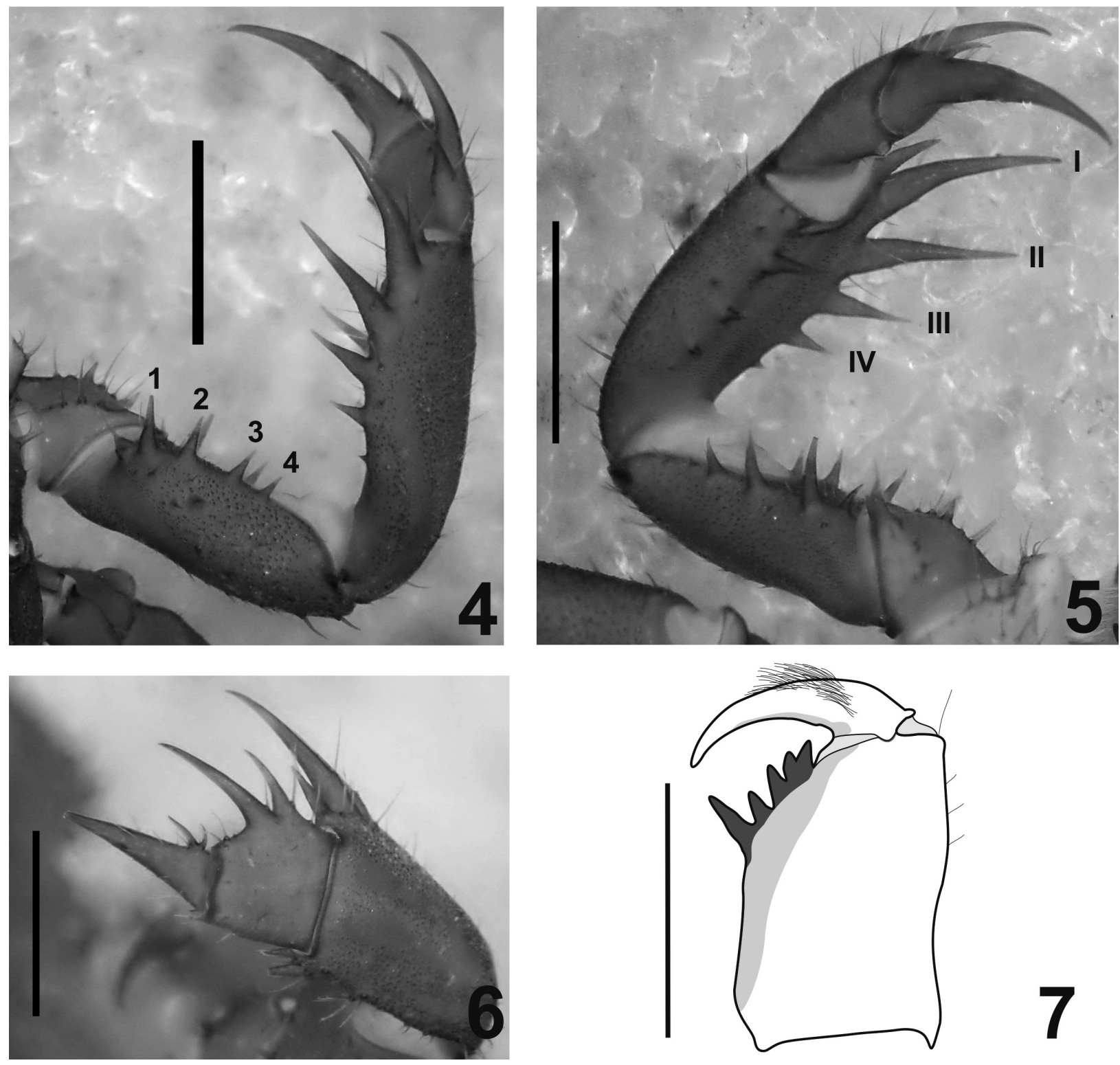

FIGURES 4-7: Sarax curioi sp. n. female holotype. 4 - Dorsal view of the right pedipalp. 2 - Ventral view of the right pedipalp. 6 - Frontal view of the left basi and distitibia. 7 - Inner view of right chelicerae. Scale bars: $1 \mathrm{~mm}$.

Pedipalp: Trochanter (Figs. 4-5): large distal, spiniform, ventral apophysis, bearing many strong setae and with a blunt tip pointed forwards; apophysis with several subequal setiferous tubercles distributed along the apophysis length. Femur (Figs. 4-5): 4 dorsal spines $(1>2>3>4)$, the first one three times bigger than the last one; prominent geminate setiferous tubercle before the first spine; 3 ventral spines $(1>2>3)$ of approximately the same length of the dorsal ones; one spine proximally placed to the first one, which is located more interiorly than the main series of spines, with a similar length of the third one, but less robust; last spine $1 / 2$ the length of the first one. Tibia (Figs. 4-5): main series with 4 spines $(\mathrm{I}>\mathrm{II}>\mathrm{III}>\mathrm{IV})$; one accessory spine anterior to spine I, with its lenght similar to spine III; one accessory spine located proximally, being almost vestigial. 4 ventral spines $(\mathrm{II}>\mathrm{I}=\mathrm{III}>\mathrm{IV})$, each 
spine with an equivalent setiferous tubercle ventrally placed. Basitarsus (Figs. 4-6): 2 dorsal spines placed approximately in the middle of the article, the basal spine about $1 / 2$ the length of the distal one. 1 ventral spine at the distal half; this spine is broken, but the diameter of its base suggests that it is smaller than the dorsal one. Distitarsus (Fig. 6): long, with 2 curved geminated spines at the basal half; distal spine larger, reaching almost $1 / 3$ of the article length; the geminated spines are located on a tubercle-like lifting that is formed by the wider base of the distal spine; the proximal spine is smaller, slender and less sclerotized (which can be noticed for its clearer color). Cleaning organ about $1 / 2$ the article length. Claw (Fig. 6): long, with an acute, curved tip.

Legs: All densely setose. Ventral corner of the prolateral face of femora II-IV projecting in a distinct spiniform process. Femur length I> III $>$ IV $>$ II. Tibia I with 21 articles and tarsus (basitarsus+distitarsus) I with 37 articles in both legs. Leg IV: Basitibia: 4 pseudo-articles, one trichobothrium at the first and one at the last pseudoarticle. Distitibia: 16 trichobothria, trichobotria $b c$, $s b f$ and $b f$ equidistant. Basitibia-distitibia length $\mathrm{BT} 1>\mathrm{DT}>\mathrm{BT} 3=\mathrm{BT} 4>\mathrm{BT} 2$. Basitarsus/distitarsus ratio $7 / 4$, distitarsus tetramerous.

Measurements: Females ( $\mathrm{n}=1)$ : Cephalothorax: Length: $2.67 \mathrm{~mm}$, Width: $3.73 \mathrm{~mm}$. Abdomen: 5.0 mm. Pedipalp: Femur $2.04 \mathrm{~mm}$, Tibia $2.21 \mathrm{~mm}$,
Basitarsus $1.04 \mathrm{~mm}$, Distitarsus $0.69 \mathrm{~mm}$, Tarsal claw $0.56 \mathrm{~mm}$.

Color pattern (in alcohol): Chelicerae, pedipalps and carapace yellowish. Legs light colored. Abdomen pale yellow.

Genitalia: Unknown. The gonopod of the specimen was destructed before it could be analyzed.

\section{Natural history}

The specimen herein described was collected on the forest floor of Malumpati. The female was carrying nine eggs.

\section{DISCUSSION}

The genus Sarax has currently 17 species and two subspecies, distributed from Greece to Papua New Guinea. Among all these species, Sarax curioi sp. n. is the only one with geminated spines on the pedipalp distitarsus, without denticles on the cheliceral claw and with 21 pseudo-articles on tibia I.

The amblypygid fauna in the Philippines is poorly known. With this new species, the number of species raises to three: Charon grayi Gervais, 1842, Sarax brachydactylus and S. curioi sp. n.. This is the first time that an amblipigid is recorded from the Panay Island, which shows that the Philippines is still a sub-sampled area. This is evidenced by the absence of species of the genus Sarax (the most diverse genus in the Southeast Asia) in three of the
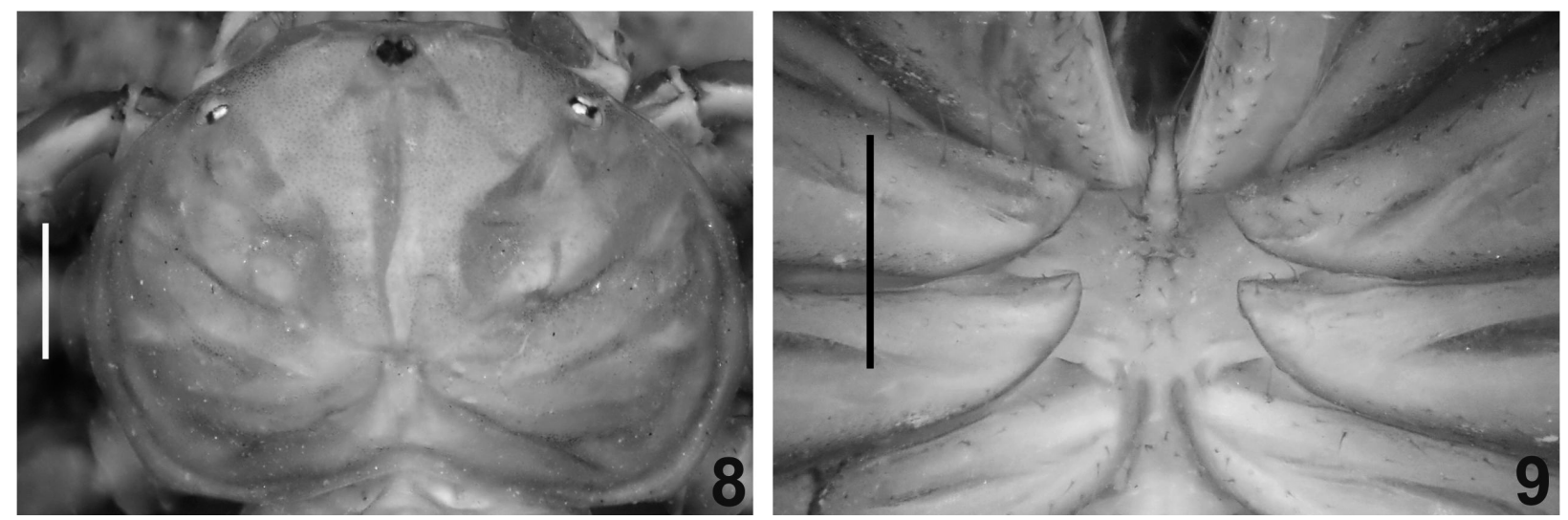

FIGURES 8-9: Sarax brachydactylus female, MNHN 14802. 8 - Carapace. 9 - Sternum. Scale bars: $1 \mathrm{~mm}$. 
seven biggest islands that constitute the country (Mindanao, Mindoro and Samar) (Fig. 14).

Sarax curioi sp. n. can be easily distinguished from the other Philippine species. The corners of the anterior margin of the carapace in $S$. curioi sp. $\mathrm{n}$ extend downwards abruptly in front of the lateral eyes (Fig. 2), which is different from Sarax brachydactylus, that has the lateral limits of the anterior margin of the carapace continued with the rest of the carapace edge (Fig. 8). The new species has the pedipalp with a strong granulation mainly on the femur and tibia, both on dorsal and ventral
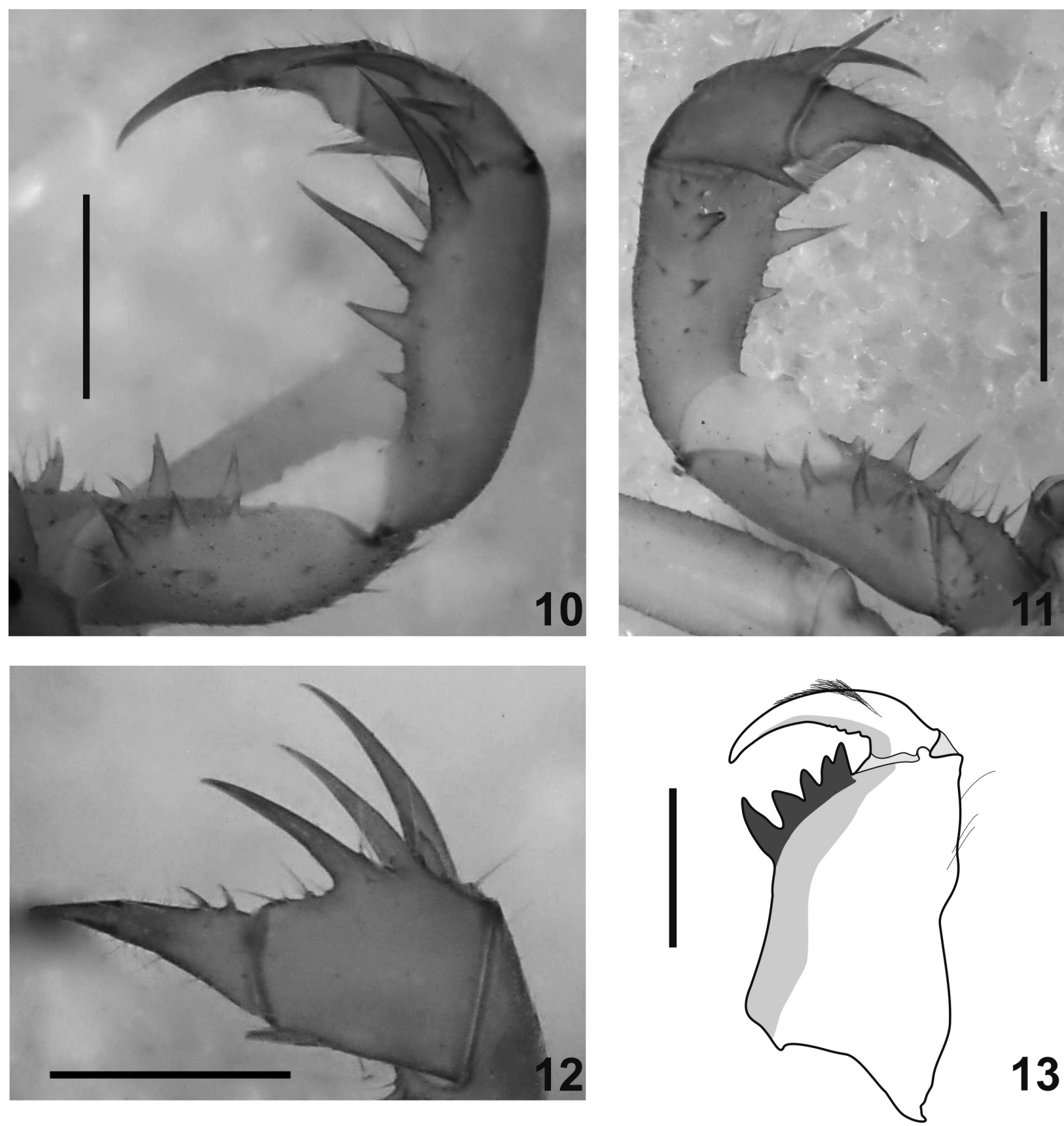

FIGURES 10-13: Sarax brachydactylus female, MNHN 14802. 10 - Dorsal view of the right pedipalp. 11 - Ventral view of the right pedipalp. 12 - Frontal view of the left basi and distitibia. 13 - Inner view of right chelicerae. Scale bars: $1 \mathrm{~mm}$. 
surfaces (Figs. 4 and 5). The granules are visibly more sclerotized and have a darker coloration when compared with S. brachydactylus (Figs. 10 and 11). Also, the shape of the basitibia of the pedipalp is different between the species; the anterior portion of the basitibia (i.e. between the distal spine and the articulation with the distitibia) in Sarax curioi sp. n. has a higher inclination (Fig. 6) when compared with S. brachydactylus (Fig. 12). Besides, the pedipalp distitibia of Sarax curioi sp. n. has a pair of geminated spines both sharing the same base (Fig. 6), while the distitibia spines of $S$. brachydactylus are clearly separated as the pattern conformation observed among the Charinidae species (Fig. 12).

Several differences can be observed concerning the chelicerae of both species. S. curioi $\mathrm{sp}$. n. has the cheliceral claw without denticles (Fig. 7), whereas S. brachydactylus has four denticles (Fig. 13). The bifid denticles of the basal segment of the chelicerae in S. curioi sp. n. are curved upwards, while in S. brachydactylus the bifid denticles point forwards; the basal denticle (the largest) is straight in S. curioi sp. n. but is curved in S. brachydctylus; the denticle that follows the basal one (the largest) is much shorter than the others in $S$. curioi sp. $\mathrm{n}$., while it is subequal in $S$. brachydactylus (but always smaller than the proximal one).

The new species can be distinguished from the other non-Philippines Sarax species by a set of characters, like the size of the individuals (e.g. $S$. curioi sp. n. is much smaller than $S$. davidovi (Fage, 1946)), the number of trichobotria on the basitibia of leg IV (S. curioi sp. $n$. has 16; S. cavernicola Rahmadi, Harvey and Kojima, 2010, S. mardua Rahmadi, Harvey and Kojima, 2010, S. sangkulirangensis Rahmadi, Harvey and Kojima, 2010 and S. yayukae Rahmadi, Harvey and Kojima, 2010 has 18; and S. davidovi has 20), the number of spines on the pedipalp distitibia (2 in S. curioi, 3 in S. cavernicola and 1 in S. monodenticulatus Rahmadi and Kojima, 2010, S. cochinensis (Gravely, 1915) and S. javensis (Gravely,
1915)), and the size of the pedipal distitibia spines (much smaller in S. sarawakensis (Thorell, 1888) and in S. rimosus (Simon, 1901) than in the new species, and not geminated like in $S$. curioi sp. n.).

New record of Asian Sarax. Sarax newbritainensis Rahmadi and Kojima, 2010 is recorded from New Ireland Island, Papua New Guinea. This is the first record of the species elsewhere of the type locality, in New Britain. Rahmadi and Kojima 2010 say that this species has on its tibia and tarsus I 23 and 41 articles, respectively, but in the specimen here analyzed 29 and 41 articles were reported, respectively.

List of the Sarax species and subspecies with its known area of occurrence:

1- Sarax brachydactylus Simon 1892: Cambodia, Malaysia, Philippines; 2 - Sarax buxtoni (Gravely 1915): Malaysia, Singapore; 3 - Sarax cavernicola Rahmadi, Harvey and Kojima 2010: Indonesia; 4a - Sarax cochinensis cochinensis (Gravely 1915): India; 4b - Sarax cochinensis bispinosus (Nair 1934): India, 5 - Sarax davidovi (Fage 1946): Cambodia, Laos, Vietnam; 6 - Sarax javensis (Gravely 1915): Indonesia (Java); 7 - Sarax mardua Rahmadi, Harvey and Kojima 2010: Indonesia; 8 - Sarax mediterraneus Delle-Cave 1986: Greece; 9 - Sarax monodenticulatus Rahmadi and Kojima 2010: Indonesia; 10 - Sarax newbritainensis Rahmadi and Kojima 2010: Papua New Guinea; 11 - Sarax rimosus (Simon 1901): Malaysia; 12 - Sarax sangkulirangensis Rahmadi, Harvey and Kojima 2010: Indonesia; 13 - Sarax sarawakensis (Thorell 1888): Andaman Islands, Indonesia (Java, Kalimantan), Malaysia (Sarawak, Selangor), Papua New Guinea, Singapore, Solomon Islands; 14 - Sarax singaporae (Gravely 1911): Malaysia, Singapore; 15 - Sarax willeyi (Gravely 1915): Papua New Guinea; 16 - Sarax yayukae Rahmadi, Harvey and Kojima 2010: Indonesia, Malaysia; 17 - Sarax curioi sp.n.: Philippines. 


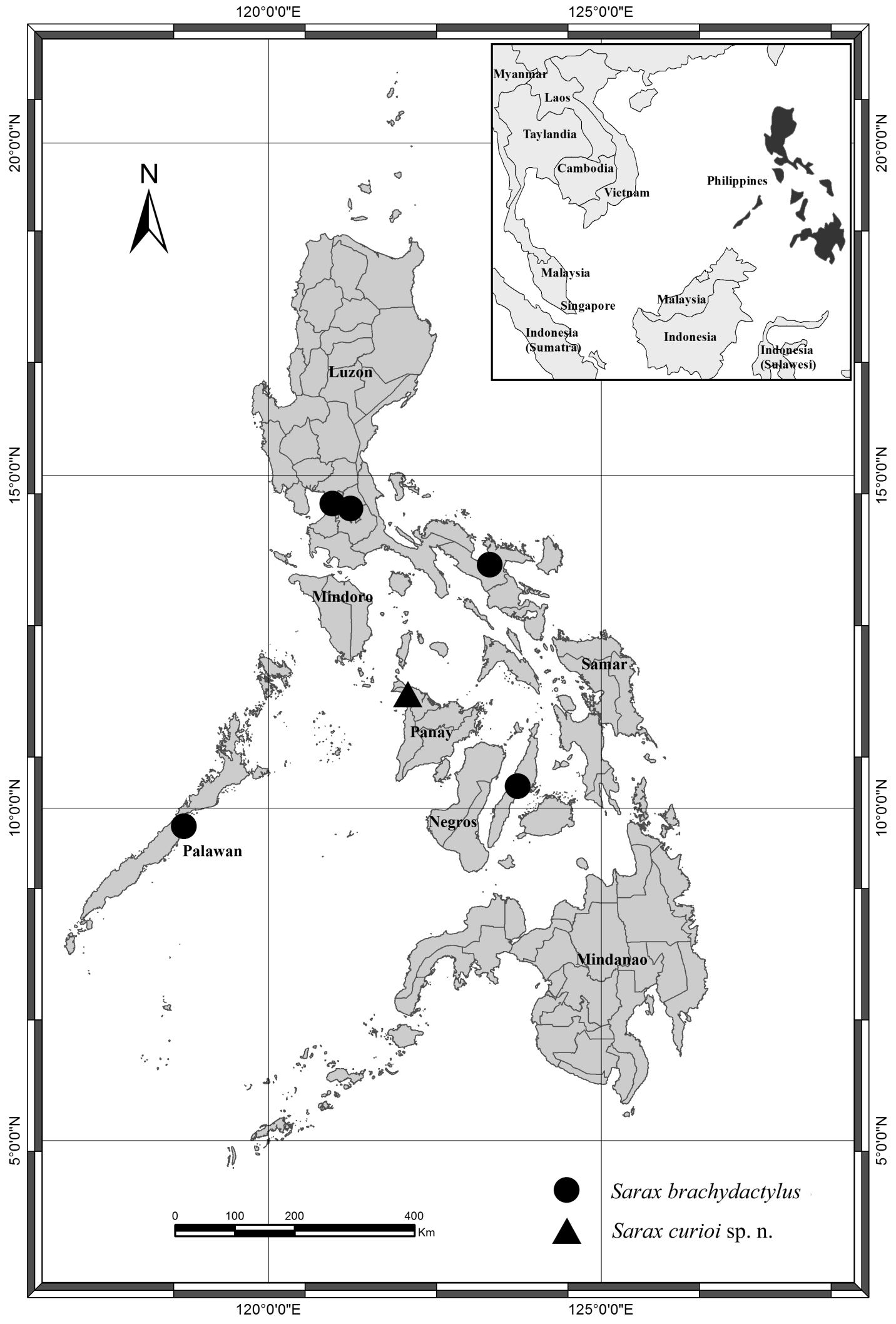

FIGURE 14: Distributional map of the Philippine species of Sarax. 


\section{ACKNOWLEDGMENTS}

We would like to thank Conselho Nacional de Desenvolvimento Científico e Tecnológico (CNPq) for the scholarship for the second author, and Dr. Ebehard Curioi who sent the specimen to us. This is publication no. 87 of PanayCon (Panay Eco-Social Conservation Project; formerly PESCP) under the auspices of the NGO PhilinCon (Philippine Initiative for Conservation of Environment and the People, Inc.).

\section{RESUMO}

Uma nova espécie do gênero Sarax Simon, 1892 é descrita da Ilha Panay, Filipinas. Sarax curioi sp. n. é a segunda espécie do gênero descrita no país e se diferencia da outra espécie filipina (Sarax brachydactylus Simon, 1892) pela superfície do pedipalpo que possui grânulos esclerosados, pelos espinhos da distitibia do pedipalpo, pelo número de dentes na garra da quelícera e pela forma dos dentes do segmento basal da quelícera. É feito um novo registro de Sarax newbritainensis Rahmadi e Kojima, 2010 para a ilha Nova Irlanda, Papua Nova Guiné.

Palavras-chave: Biodiversidade, Sudeste Asiático, Taxonomia, Amblipígio.

\section{REFERENCES}

BAPTISTA RLC AND GIUPPONI APL. 2002. A new troglomorphic Charinus (Arachnida: Amblypygi: Charinidae) from Brazil. Rev Ibér Aracnol 6: 105-110.

HARVEY MS. 2002. The first old world species of Phrynidae (Amblypygi): Phrynus exsul from Indonesia. J Arachnol 30: 470-474.

HARVEY MS. 2003. Catalogue of the Smaller Arachnid Orders of the World: Amblypygi, Uropygi, Schizomida, Palpigradi, Ricinulei and Solifugae, Collingwood, Victoria, Australia: CSIRO Publishing, 398 p.

QUINTERO DJ. 1981. The amblypygid Phrynus in the Americas (Amblypygi, Phrynidae). J Arachnol 9: 117-166.

RAHMADI C, HARVEY MS AND KoJIMA J. 2010. Whip spiders of the genus Sarax Simon 1892 (Amblypygi: Charinidae) from Borneo Island. Zootaxa 2612: 01-21.

RAHMADI C, HARVEY MS AND KoJIMA J. 2011. The status of the whip spider subgenus Neocharon (Amblypygi: Charontidae) and the distribution of the genera Charon and Stygophrynus. J Arachnol 39: 223-229.

RAHMADI C AND KoJIMA J. 2010. Whip spiders of the genus Sarax in the Papuan region, with description of two new species (Amblypygi, Charinidae). J Arachnol 38: 475-484.

Weygoldt P. 2000. Whip Spiders: Their Biology, Morphology and Systematics, Stenstrup, Denmark: Apollo Books, 164 p. 